\title{
Protein S100-A7
}

National Cancer Institute

\section{Source}

National Cancer Institute. Protein S100-A7. NCI Thesaurus. Code C143080.

Protein S100-A7 (101 aa, $11 \mathrm{kDa}$ ) is encoded by the human S100A7 gene. This protein is involved in antimicrobial activity, calcium binding and epidermal development. 